\title{
Evaluation of Sports Trainers Perceptions on Computer Aided Education Related to the Attitudes toward Learning
}

\author{
Talha Murathan', Oktay Kaya ${ }^{2, *}$ \\ ${ }^{1}$ School of Physical Education and Sports, Ardahan University, Turkey \\ ${ }^{2}$ School of Physical Education and Sports, Kafkas University, Turkey
}

Copyright $(\mathcal{C} 2016$ by authors, all rights reserved. Authors agree that this article remains permanently open access under the terms of the Creative Commons Attribution License 4.0 International License

\begin{abstract}
Technologic developments have - the same as they have done it in every sector- influenced the education system. These influences have forced to use the computer in the education-training applications within the education system. The aim of this research is to determine, compare, and examine the influences on the conduct for learning of sport educators towards their perceptions of Computer Aided Education. In this context the perception levels of sport educators related with computer aided education was revealed, the risk factors and their conduct for learning was determined. Furthermore, the variables which might affect their conduct for learning with computer aided education were determined. The population of research was composed of sport educators in Turkey. The sample group was composed of 616 male and 278 female sports educators in the school year 2012-2013. The obtained data was analyzed using SPSS 17.0 statistical package program. In the end of this research, it had been seen that the perception of sport educators of computer aided education was above the average. Also it was concluded that significant differences exist on sub-dimensions toward their conduct for learning. Relationship between perceptions of sport educators towards computer-aided education in terms of conduct for learning were above average, also has a strong, positively and significantly relationship were determined $(\mathrm{r}=0.596)$.
\end{abstract}

Keywords Computer Aided Education, Sport Educators, Conduct for Learning

\section{Introduction}

The thought of training the body which forms the unity of the ideal and spiritual features of human being, for certain aims is as old as human being on universe [1]. In this frame, societies have given great importance to sports education which enables the development of mental, emotional and social as well as the physical development of human [2]. Thus, sport facilities have become a crucial part of the human life nowadays. Moreover approaches of media to sports, coping with stress, efforts of keeping their bodies fit and also international successes in sports have gained importance and in the daily lives of society and morale levels. Those helped sports to gain a contemporary aspect [3].

One of the most important basic requirements of reaching of the sportsman to the expected level is to have well-educated and intellectual, skillful, talented coaches who can perform in all levels. It is an obligation to educate and improve coaches trained in a model in different sports branches considering the features of those branches. For that reason a coach trained by using scientific facilities with the essential principles trains his/her sportsman in the best way. One of the institutions which are directly related to train coaches in our country is higher education institutions training physical education and sports teachers and the other is General Directorate of Youth and Sports [4].

Definitely, when it comes to trainer staff in sports the first thing coming to mind is coaches and physical education teachers. Sports trainers called coaches in sports have great part in the development of sports. The more a coach is informed, trained in an adequate training program and later have a chance of better working conditions, the more trainees will show performance. Başer states that essential knowledge and skills may be provided by an essential education in order to be successful in his/her branch, one should be a psychologist, sociologist, training expert when required [5].

Teacher, another sports trainer is the most fundamental member of education given in schools. Teachers play leading role in development of a country, brought up of skillful human resources, providing peace and social reconciliation, socializing of the individual and preparing for the societal life, transferring the values and culture of society to youth. Teachers are the real architects of societies and also artists shaping human personality [6]. 
A teacher is an individual designer who can transfer complex skills directs and shapes human behaviors. A teacher is not only a scientist who tries to contribute to the society and education sciences with his/her implementations and responsible towards society but also a philosopher transferring social and universal values to generations possessively. At the same a teacher is a psychologist, educator, sociologist, and technocrat except from the definitions in legislations [7].

Developing technology provides us different opportunities .Countries struggle for improving the quality of the human resources that the future requires with the new developments. In accordance with these attempts the importance of knowledge increases. This increase caused information societies and changed life styles of societies. Technological developments affect all areas as well as educational systems. These effects entail using computers as a product of scientific and technological developments in educational applications in educational institutions,

The population of Turkey increases in a rate of 18,35 per thousand and a big part of this population is composed of youth under 21 [8].The importance of the matter is clear for such a country whose population is young and dynamic. Rapid increase in population brings some problems. These problems are seen as lack of classes, teachers, schools and materials. The solution of those problems lay in meeting of the requirements of education institutions with their teachers and students.

Scientific and technological developments not only entail new educational requirements but also they provide new opportunities to educational applications. Computers are one of the leading opportunities. Computers have been used in every part of society also they have become an indispensable part of daily life. By 1950, teaching materials had been teacher course book, blackboards etc. After 1950, the question "Should computer be used in education?" aroused [9]. Nowadays, The question "Should computer be used in education? "Substitute for the question "How a computer should be used in education efficiently? The widespread usage of computers in social life and adaptation of people to this new social life require familiarization and skills for computers. It is possible for people to be educated on computers via placing computer classes in their curriculum [10].

In the light of all those information this study aims to compare examine and determine the perception levels of sports trainers related to computer aided education, effects on attitudes related to learning.

\section{Material and Method}

\section{Objective}

This study aims to compare examine and determine the perception levels of sports trainers related to computer aided education, effects on attitudes related to learning in the education term of 2012-2013 .In this context, risks factors and attitudes towards learning are determined by revealing the perception levels of sports trainers related to computer aided education. Variances affecting the perception levels of sports trainers related to computer aided education has been determined. In the light of gathered information It has been aimed to determine the direction of relation between the perception levels of sports trainers related to computer aided education and attitudes towards learning with correlation tests.

\section{Population and Sample}

Population is consisted of sports trainers in Turkey. Sample calculation methods related to number of population are not used while determining sample number, for it is not aimed to estimate with a determined sensitively.. The most suitable sample group is determined by using $\mathrm{n}=$ $\mathrm{Nt} 2 \mathrm{pq} /[\mathrm{d} 2(\mathrm{~N}-1)+\mathrm{t} 2 \mathrm{pq}]$ formula for sample group. Moreover Attention has been paid to provide required minimum sample size for suitable statistical analysis of suitable sample sizes to be reached. In this study required minimum sample size has been calculated as 924 people because there are 2 freely estimated parameters to be tested in structural equation modeling. Study has been conducted on a sample with 894 people in defiance of missing data.

In 2012-2013 education terms there were 14050 active sports trainers in Turkey. In this context there were 894 volunteers taking part in study on the internet.

\section{Data Collection Tools}

In the study two scales were published on the internet blog as a data collection tool. Attitude scale for computer aided education (BDEYİÖ) developed by (ARSLAN 2006) was used to evaluate perceptions of computer aided education. Attitude scale related to learning (ÖITÖ) whose validity, reliability studies done developed by (KARA, 2010) was used to determine the attitudes of sports trainers related to learning. Besides demographic information and personal information form were added to the first page of scales by researcher [11] [12].

\section{Findings}

When the data in table 1 is examined, it has been determined that $68,90 \%$ of the participants are male and 31 , $09 \%$ female. Again in the same table when age states of participants are examined, it has been determined that 30 , $20 \%$ of the participants are at the age of 25 and under, 27, $06 \%$ between $26-35$ and $42,72 \%$ are 36 and over.

On the personal information form the participants are asked to answer a question "what is your vocational satisfaction level". There has been a classification on the choices as low-medium-high level. As a result, regarding participants' declarations vocational satisfaction levels have been determined that $70,69 \%$ are at low level $23,60 \%$ are 
medium and 5,70\% are high level .When income levels of sports trainers are examined, it can be clearly understood from the table that $20,35 \%$ of the participants have $1000 \mathrm{TL}$ and under monthly income, $36,46 \%$ of the participants have monthly income between 1001-2000 TL , 29,30\% participants monthly income 2001-3000 TL and 13,87\% participants have monthly income of $3001 \mathrm{TL}$ and over.

Table 1. Demographic features of sports trainers taking part in the study

\begin{tabular}{ccc}
\hline Features of Sports Trainers & N (\%) \\
\hline \multirow{2}{*}{ Sex } & Male & $616(68,90)$ \\
& Female & $278(31,09)$ \\
\hline \multirow{2}{*}{ Age } & 25 age and under & $270(30,20)$ \\
& $26-35$ age & $242(27,06)$ \\
& 36 age and over & $382(42,72)$ \\
& $1-5$ years & $298(33,33)$ \\
Vocational & $6-10$ years & $314(35,12)$ \\
Experience & $11-15$ Years & $142(15,88)$ \\
& $16-20$ Years & $76(8,50)$ \\
& 21 years and over & $64(7,15)$ \\
Level of vocational & Low & $632(70,69)$ \\
satisfaction & Medium & $211(23,60)$ \\
& High & $51(5,70)$ \\
\hline \multirow{3}{*}{ Income Level } & 1000 TL and under & $182(20,35)$ \\
& $1001-2000 \mathrm{TL}$ & $326(36,46)$ \\
& between & $262(29,30)$ \\
& $2001-3000$ TL & $124(13,87)$ \\
\hline & between &
\end{tabular}

Table 2. Distribution of Points for perceptions of computer aided education

\begin{tabular}{cccccc}
\hline & N & $\begin{array}{c}\text { Lowest } \\
\text { Point }\end{array}$ & $\begin{array}{c}\text { Highest } \\
\text { Point }\end{array}$ & Average & ss \\
\hline $\begin{array}{c}\text { Points for } \\
\text { perceptions } \\
\text { of computer } \\
\text { aided } \\
\text { education }\end{array}$ & 894 & 34 & 93 & 71,95 & 13,91 \\
\hline
\end{tabular}

Standard deviation as seen in the table 2 the average point of sports trainers' perception of computer aided education is 71,95 , standard deviation is 13,91 the highest perception point is 93 and the lowest perception point is 34 . According these values, sports trainers' perception of computer aided education corresponds to "I agree" category. This finding shows that sports trainers' perception of computer aided education is positive and they rely on themselves.

As seen in table 3, as a result of analysis of variance there is a statistically significant difference between points of sports trainers' perception of computer aided education and vocational experience status $(\mathrm{p}<0.05)$.It has been understood from the table that sports trainers whose vocational experiences are low but points for perception of computer aided education are high. In the light of gathered information, It has been determined that the statistically significant difference is among sports trainers whose vocational experiences are between 1-5, 1-4, 1-3, 2-5, 2-4 and 2-3. According to this, it can be said that the perception levels of computer aided education of whose vocational experience is over 15 years are higher than the ones whose vocational experiences are under 15 years.

Table 3. The results of variance analysis of sports trainers' perceptions of computer aided education according to their vocational experiences.

\begin{tabular}{ccccccc}
$\begin{array}{c}\text { Vocational } \\
\text { Experience }\end{array}$ & $\mathbf{N}$ & $\overline{\boldsymbol{X}}$ & Ss & sd & $\mathbf{p}$ & $\begin{array}{c}\text { Significant } \\
\text { difference }\end{array}$ \\
\hline $\mathbf{1 - 5}$ Years & 298 & 74,72 & 10,71 & & & \\
$\mathbf{6 - 1 0}$ Years & 314 & 74,96 & 12,92 & & & \\
$\mathbf{1 1 - 1 5}$ Years & 142 & 66,85 & 13,14 & 792 & 0.000 & $1-3,2-5,1-4$, \\
$\begin{array}{c}\text { 16-20 Years } \\
\text { 21 Years } \\
\text { and over }\end{array}$ & 76 & 65,23 & 12,98 & & & $2-4,2-3$ \\
\hline
\end{tabular}

Table 4. The results of independent groups T-test related to attitude of learning in terms of sex status of sports trainers.

\begin{tabular}{ccccccc}
\hline Sub-dimension & Sex & $\mathbf{N}$ & $\boldsymbol{x}$ & ss & $\mathbf{t}$ & $\mathbf{p}$ \\
\hline $\begin{array}{c}\text { Nature of } \\
\text { Learning }\end{array}$ & Male & 616 & 29.11 & 3.59 & & \\
Female & 278 & 30.85 & 3.15 & & .01 \\
$\begin{array}{c}\text { Concerns over } \\
\text { learning }\end{array}$ & Male & 616 & 39.41 & 8.27 & & \\
Expectations & Male & 616 & 37.19 & 4.17 & & \\
from learning & Female & 278 & 39.74 & 4.51 & & .00 \\
Availability to & Male & 616 & 40.11 & 6.55 & & \\
learn & Female & 278 & 47.74 & 6.17 & -6.27 & .00 \\
\hline
\end{tabular}

In table 4 "sub-problem of the research" it has been evaluated whether there is a significant difference in sports trainers' attitudes related to learning in terms of their sex or not.

There is a difference in the average of given answers to attitude of learning in terms of sex status of sports trainers. Significant differences have been observed in 4 sub-dimensions according to independent groups $\mathrm{T}$-test results done to determine whether differences are significant or not. It is determined that there are statistically significance in the averages of dimensions between the nature of learning for male and female trainers $X_{\text {erkek }}=29,11, X_{\text {kadm }}=30,85$, $X_{\text {erkek }}=29,11$ and again in sub-dimension of expectations $X_{\text {erkek }}=37,19, \quad X_{\text {kadn }}=39,74$, in the sub-dimension of availability to learn $X_{\text {erkek }}=40,11, X_{\text {kadn }}=47,74$.

In sub-dimension of concern over learning it has been observed that male sports trainers have a higher significant average than female sports trainers. ( $x$ male $=39.41$, $x$ female $=28.54$ ). According to the data on the table It can be said that male sports trainers are more discontented than females. 
Table 5. The Correlation Test Results between Attitudes related to Learning and Perceptions of Computer Aided Education of sports trainers

\begin{tabular}{cccc}
\hline & & $\begin{array}{c}\text { Perception of Computer } \\
\text { Aided Education }\end{array}$ & Attitude related to learning \\
\hline Perception of Computer & Pearson Correlation & 1 & $.596\left(^{*}\right)$ \\
Aided Education & $\mathrm{P}$ & & .000 \\
& $\mathrm{~N}$ & 894 & 894 \\
\hline \multirow{2}{*}{ Attitude related to learning } & Pearson Correlation & $0.596\left(^{*}\right)$ & 1 \\
& $\mathrm{P}$ & .000 & 894 \\
\hline
\end{tabular}

According to table 5 , the relation between attitudes related to learning and perceptions of the participants in computer aided education is over the average and also it has been determined that there is a strong positive and significant relation $(\mathrm{r}=0.596)$.

In the light of the gathered data it has been determined that there is a significant differences in terms of different variances sports trainers' perception points for computer aided education. However, significant differences in terms of variances have been understood from data in sub-dimensions of attitude related to learning of sports trainers. Moreover, strong positive and significant relation between attitude related to learning of sports trainers and points for perception of computer aided education.

\section{Discussion and Result}

Research sample is consisted of $616(68,90 \%)$ male and $278(31,09 \%)$ female volunteer physical education teacher and coaches who are defined as sports trainers in the 2012-2013 education term. Data values obtained from research analysis have been calculated for percentage (\%), standard deviation (ss) and standard error (\#).Crosstab analysis $\mathrm{x}^{2}$ test has been regarded as $\mathrm{p}<0.05$ significance level in statistical evaluation of data. Moreover, Pearson Multiplication Momentum Correlation is used to determine the relation level and direction in terms of variances in the evaluation.

It has been determined that vocational satisfaction level of $70,69 \%$ is at low level $23,60 \%$ at medium level and 5,70 at high level according to declaration of the sports trainers (table 1).Besides, it has been understood from the table that $20,35 \%$ of the sports trainers have a monthly income of 1000 TL and under, 36,46 \% between 1001-2000, 29,30\% between 2001-3000, 13,87\% $3001 \mathrm{TL}$ and over. Keklik Y (2007) studied education directors' perceptions of computer aided and in his study it is understood that vocational satisfaction levels of education directors are low [13].

$77,06 \%$ (689 participants) of the participants declared that they have at least one computer and it is also understood the data that 22,94\% (205 participants) of the participants do not have their own computers. It is clear on the table that 44 , $88 \%$ (448 participants) attended a computer course ones in a life time and the rest $50,11 \%$ (894 participants) declared that they haven't attended any computer courses. Moreover, $65,10 \%$ (582 participants) expressed that they want to attend a computer course with a intention of learning ,but $34,89 \%$ (312 participants) had no intention of attending a course. In a study conducted by Swan (1995) state of having a computer in the process of computer aided education was studied and it was understood that $12,5 \%$ of the participants had computers. In our study state of having greater numbers of computers can be explained by widespread usage of technology related to the development of technology [14].

It has been determined that on behalf of the participants who are good at using computer, there is a statistically significant difference between the perceptions of computer aided education and basic computers skill levels. Moreover, there is a statistically significant difference among sports trainers perception of computer aided education, frequency of computer usage and level of computer skills on behalf of the participants who are good at computer skills and using computers more frequently. In this situation, perception can be related to exact and true lives and former experiences as Bandura stated (1995).Thus, the result shows parallelism with the results found by Keskinkilıç and Alabay(2006),Seferoğlu (2005),Aşkar and Umay (2001). But the result of this study contradicts to the result of Yilmaz and friends study 2006 because the study does not show difference in the perception of self-sufficiency related to computer aided education according to the computer use experiences and frequency of computer use [15]. According to Cambaz's study (1999) which is one of the studies on computer aided education, teachers' attitudes toward computers did not show difference by gender. Similarly in the study conducted by Ünaldı (2003), teachers' attitude toward computer assistance in education did not show difference by gender. In the study conducted by Aydoğdu (2003) "The attitude of secondary school geography teachers toward computer aided education", teachers' attitude toward computer assistance in education did not show difference by gender. Hizal (1989) expresses in "the evaluation of teachers' opinions on computer education and computer aided education" that regardless of teachers' genders, their attitudes toward computer aided education are positive and they are interested in such applications. It is understood that by Deniz's (2005) study "the attitudes toward computers of form and branch teachers working in primary schools" that there is no difference between the sub-scales of computer concern and computer aided education when examined by sub-scales whether on teachers' attitude toward computers show difference by gender. Çelik and Bindak (2005) concluded in their research that the difference between male 
and female teachers' points on their attitude toward computers is statistically insignificant. Research findings are found supporting former research results. [16] [17]

Yildirım (2006) concludes in his article "the use of information technologies in primary school first stage" questioning that in the world of electronic devices are often used lack of attention caused by the unconscious use of computers, attitude against society, insufficient motivation, depression and inefficient study habits are prevented.

Gürol (1990) in his masters' thesis "opinions and attitudes toward computer as an education material", expresses that teachers play a key role in use of computers. Gürol also warns that there will not be efficient participation of teachers unless they know the limits and advantages in education. Most of the teachers who are not familiar with technologic materials and tools feel worried. It is expressed that the more teachers are familiar with the tool and comprehend its significance on educations such negative attitudes will disappear [18].

In our study, it is determined that the observed differences between male and female sports trainers' nature of learning, expectations from learning and availability to learn are statistically significant. Therefore, it is seen that female sports trainers understand better the nature of learning and their expectations from learning are higher and they are more available to learn. It is concluded that male sports trainers have more significantly higher average on concerns over learning than females have.

The sports trainers whose seniorities are between 1-5 years have the highest expectations from learning. The ones whose seniorities are 21 years and over have the lowest expectations from learning; the differences between the averages of availability to learn are statistically significant. The sports trainers whose seniorities are between 1-5 years have the highest level of availability to learn. The ones whose seniorities are 11 years and over have the lowest level of availability to learn; As the seniority of the sports trainers increases, their tendency toward availability to learn improves significantly.

Kruskal-Wallis test is used to determine the dimensions of concern over learning $\left(\mathrm{p}_{\text {açılık }}>0,05\right)$ and expectations from learning and availability to learn ( $p_{\text {açiklık }}$ ve $p_{\text {beklenti }} 0,05$ ). According to the test results, it is understood that the sports trainers whose seniorities are between 1-5 years are significantly more concerned than the trainers between seniorities of 6-10 and 11-15 years (Table 4). It can be concluded that the general concern levels of sports trainers on their early career affects their concern over learning. Kara (2010) concludes in his study that the attitude toward learning may differ significantly in individuals related to their work experience and age status. Our study shows parallelism with Kara's (2010) study findings [12]. In the light of the above findings, information and communication technologies which rapidly develop are indispensable aspects for sports trainers in education. The importance of computer aided education should be shown to all sports trainers in all grades of education in order to improve those education facilities well enough. Educators using these technologies should be asked for their opinions in order to provide them educational technologies. As the result of this study, it is advised to organize a team by MNE, HEB and GDYS to provide education materials.

\section{REFERENCES}

[1] ALPMAN, C., "Eğitim Bütünlüğü İçinde Beden Eğitimi ve Çağlar Boyunca Gelişimi”, Birinci Bölüm, Milli Eğitim Basımevi, İstanbul, 1972.

[2] ARUN, A. C., "Türkiye'de Cumhuriyet Devrinde Beden Eğitimi Öğretmeni Yetiştirme Çalışmaları ve Aşamaları", Spor Bilim Dergisi, Sayı: 1, İstanbul, 1991.

[3] ÖZER, K., "Sporda Eğitim ve Öğretim", Spor Şuras1 Bildirileri, Başbakanlık Gençlik ve Spor Genel Müdürlüğü Yayım, Ankara, 1990.

[4] KALKAVAN, A., KARAKUŞ, S., EYNUR, B., R., DEMIREL, M.,"Avrupa Birliği Uyum Sürecinde Spor Eğitimi Ne Olmalıdır?", Uluslararası AB Müzakere Sürecinde Türkiye'nin Sosyo-Ekonomik ve Siyasi Yapısındaki Değişim ve Dönüşümler Sempozyumu Bildiriler Kitab1, Dumlupınar Üniversitesi, Kütahya, 2006.

[5] BAŞER, E., Performans Sporunda Psikolojinin Rolü, Beden Terbiyesi ve Spor Genel Müdürlüğü Yayınları, Ankara, 1987.

[6] ÖZDEN, Y., “ Eğitimde Dönüşüm Eğitimde Yeni Değerler”, Ankara: Pegem Yayıları, 1999.

[7] ŞEN, B., “Sınıf Öğretmeni Adaylarının Öğretmenlik Tutumları v e Ders Çalışma Stratejileri Arasındaki İlişki”, Yayınlanmamış Yüksek Lisans Tezi, Marmara Üniversitesi Eğitim Bilimleri Enstitüsü, 2006.

[8] http://www.tuik.gov.tr / Erişim: 11.06.2013

[9] KARAKUŞ, A.G., “Dünyada ve Türkiye'de Bilgisayar Destekli Eğitim Uygulaması", (Yayımlanmamış Yüksek Lisans Tezi), İstanbul, 1993.

[10] YAŞAR, Ş., "Bilgisayar, Eğitimde Bilgisayarların Etkili Kullanımı", (Edit: Y. Hoşcan) Anadolu Üniversitesi, Açıköğretim Fakültesi Yayınları, No:582, Eskişehir, 1998.

[11] SAĞLAM, H., "İlköğretim okullarında Görev Yapan Eğitim Yöneticilerinin Bilgisayar Destekli Eğitim İle İlgili Tutumlarının İncelenmesi”, Yüksek Lisans Tezi, Yedi tepe Üniversitesi, Sosyal Bilimler Enstitüsü, İstanbul, 2006.

[12] KARA, A., “Öğrenmeye İlişkin Tutum Ölçeğinin Geliştirilmesi”, Elektronik Sosyal Bilimler Dergisi, sf:32, Bahar-2010.

[13] KEKLİK, Y., "Eğitim Yöneticilerinin Bilgisayar Destekli Eğitim Hakkındaki Görüşleri”, Yıldız Teknik Üniversitesi, Sosyal Bilimleri Enstitüsü, Yüksek Lisans Tezi., sf:42-43, 2007.

[14] SWAN, K. (www.iste.org/Puplications/JRCE/jrce26.1.html). 2005. 
[15] KALKAVAN, A, ve ark.,"KTÜ Beden Eğitimi Bölümü Öğretim Elemanları ve Öğrencilerinin Beden Eğitimi Öğretmenliği İle İlgili Görüş ve Önerileri”, U.Ü., II. Ulusal Beden Eğitimi ve Spor Öğretmenliği Sempozyumu, Bursa.sf:16. 2001.

[16] BİLGiN, H., "Okul Öncesi Eğitim Kurumlanında Çalışan Öğretmenlerin Öğretmenlik Tutumlarının İncelenmesi”, Yayınlanmamış Yüksek Lisans Tezi, Marmara Üniv. Sosyal Bilimler Enstitüsü, 1996.
[17] ÜSTÜNDAĞ, N. “Müfredat Laboratuvar Okullarında Görev Yapan Yönetici ve Öğretmenlerin Bilgisayar Tutumları İle Kayg1 Düzeyleri Arasındaki İlişkinin İncelenmesi”, Yayınlanmamış Yüksek Lisans Tezi.İstanbul; Marmara Üniversitesi, Eğitim Bilimleri Enstitüsü, 2001.

[18] GÜROL, M. "Eğitim Aracı Olarak Bilgisayara İlişkin Öğretmen Görüş ve Tutumları", Yayınlanmamış Yüksek Lisans Tezi, Elazı̆̆; Fırat Üniversitesi, Teknik Eğitim Bilimleri Bölümü, 1990. 